\title{
Initial Topography
}
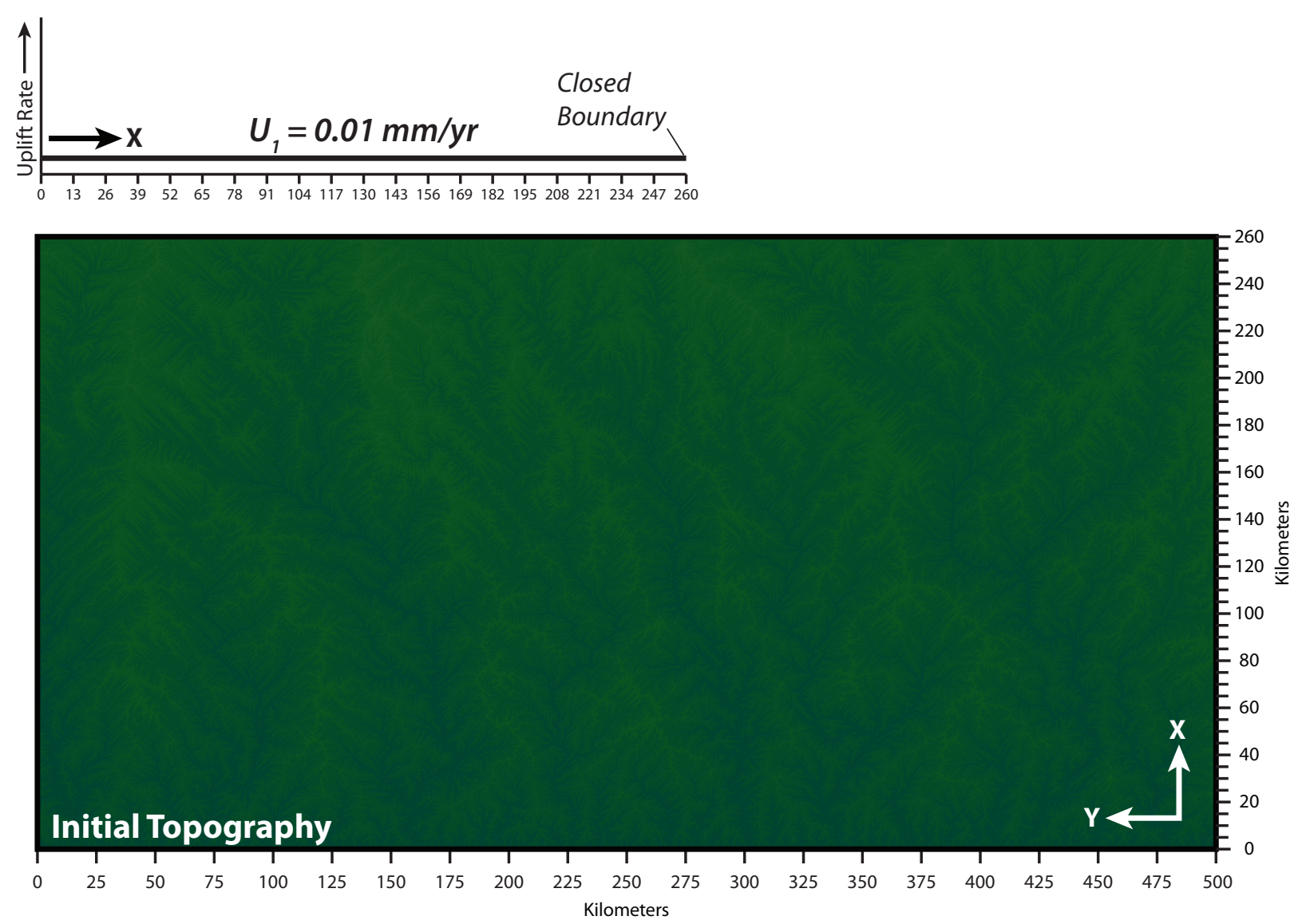

Figure S2 